\title{
Clinical experience with a novel bovine collagen dura mater substitute
}

\author{
Bruno Silva Costa', George de Albuquerque Cavalcanti-Mendes², \\ Marcelo Sartori de Abreu ${ }^{3}$, Atos Alves de Sousa ${ }^{4}$
}

\begin{abstract}
Dural substitutes are used to achieve watertight closure of the dura mater when adequate closure is not possible. The purpose of this study was to evaluate the efficacy and safety of a new collagen matrix dural substitute (Duradry, Technodry, Belo Horizonte MG) in the repair or expansion of cranial and spinal dura mater. Method: Thirty patients, operated on between March and September, 2008, were studied. Surgical records were reviewed for sex, age, location of graft, technique, and presence of fistula or infection. The patients were followed up for at least 3 months, and presence of complications, such as cerebrospinal fluid leakage, infection, asseptic meningitis hydrocephalus, pseudomeningocele, was analyzed. Results: Only one patient presented cerebrospinal fluid fistula. No patients presented wound infections, hydrocephalus, pseudomenigocele, meningites, brain abscesses or signs of toxicity related to the dural substitute. Conclusion: The new dural substitute used in this study is effective and safe, and the initial results are similar to those of other dural substitutes reported in the literature.
\end{abstract}

Key words: cerebrospinal fluid leak, duraplasty, collagen matrix.

Experiência clínica com um novo substituto dural derivado de matriz de colágeno bovino

\section{RESUMO}

Substitutos de dura máter são utilizados quando não conseguimos um fechamento dural hermético. O objetivo deste estudo foi avaliar a eficácia e segurança de um novo substituto dural derivado de matriz colágena bovina (Duradry, Tecnodry, Belo Horizonte MG) no reparo ou expansão da dura máter craniana ou espinhal. Método: Trinta pacientes operados entre março e setembro de 2008 foram estudados. Foram analisados sexo, idade, localização do enxerto, técnica e presença de fístula ou infecção. Os pacientes foram acompanhados por, pelo menos, 3 meses e a presença de complicações como fístula liquórica, infecção, meningite asséptica, hidrocefalia, pseudomeningocele foram analisadas. Resultados: Apenas um paciente apresentou fístula liquórica. Nenhuma infecção de ferida cirúrgica foi observada. Também não ocorreram casos de hidrocefalia, pseudomeningocele, meningite, abscesso ou sinais de toxicidade relacionada ao implante. Conclusão: $O$ novo substituto dural utilizado neste estudo é seguro e efetivo e os resultados iniciais são semelhantes aos de outros substitutos durais descritos na literatura.

Palavras-chave: fístula liquórica, duroplastia, matriz de colágeno.

\section{Correspondence}

Bruno Silva Costa

Rua Pasteur 89/ 706

30150-290 Belo Horizonte MG - Brasil

E-mail:costabs@gmail.com

Received 14 April 2010

Received in final form 28 October 2010

Accepted 4 November 2010
The hermetic closure of the dura mater is essential to prevent cerebrospinal fluid (CSF) fistula and its complications, such as pneumocephalus, pseudomeningocele, meningites, hydrocephalus, and so on, which are significant factors of morbidity and mortality ${ }^{1,2}$.

It is sometimes impossible to obtain dural closure in a watertight manner because of dural retraction, extensive dural 
injury during craniotomy, or neoplastic invasion. Some other times, it is important to have an expansion of the dura mater, as in decompressive craniotomy and surgical treatment of Chiari malformation ${ }^{3}$. In both cases, the use of dural substitutes could be indicated.

A dural substitute should ideally not induce immunological or inflammatory response nor present neurotoxicity. Besides, as the graft provides biomatrix for a new conjunctive tissue structure to develop, for the endogenous neodura to grow, it must be promptly absorbed. But it should not adhere to the normal surrounding tissues (brain, cortex, bone). The material should provide watertight closure, keep its shape, and not rupture. Other very important features of an ideal dural substitute are the absence of viral and prion risk of infection and an adequate final cost.

The substitutes derived from collagen have recently been highly accepted as they are close to this ideal substitute.

The purpose of this study was to investigate the efficacy and safety of a new dural substitute, derived from bovine collagen (Duradry, Technodry, Belo Horizonte MG) in the peroperative repair or expansion of the cranial and spinal dura mater.

\section{METHOD}

The present study was carried out in the Neurosurgical Department at Santa Casa Hospital of Belo Horizonte (Minas Gerais, Brazil), including 30 patients operated between March and September, 2008. The project was previously approved by the Ethics in Research Committee of the Hospital. The decision to perform a duroplasty was the assessment of the neurosurgical team during the procedure. Eleven patients were male and 19 female, and age ranged between 18 and 76 years, with an average of 48.4 years.

All the patients included in this study were followed up in the postoperative period for at least 3 months, except for 2 patients who died before this period. None of the deaths was directly related to the duroplasty. Distribution by sex, age, location of the graft, technique, and presence of fistula or infection in the postoperative period were analyzed.

The graft (Duradry, Technodry, Belo Horizonte MG) is presented in two forms: film and sponge. The film is used whenever suture is possible, whereas the sponge is applied when suture is impossible, being used or not together with fibrin glue (TISSUCOL - Baxter). Table 1 shows the types of grafts and the techniques used on the patients included in this study. In most cases, the sponge graft was placed directly on the brain without glue or suture, covering the dural lesion. In the five cases film was used, the graft was fixed by stitches or completely su- tured to the remaining dura mater. The surgical team decided the choice of graft type and technique during the surgery, as the conditions of the surgical field were faced.

The film was cut into a size and shape compatible with the dural lesion and then sutured to the dura mater with 4-0 Prolene ${ }^{\circ}$. The sponge was cut slightly larger than the dural lesion and placed either under or over the defect. Fibrin glue was applied if necessary, on interface between the graft and the remaining dura mater.

All patients were followed up after discharge, on the $30^{\text {th }}$ and $90^{\text {th }}$ postoperative days. The presence of cerebrospinal fluid leak, infection or new neurological deficits was investigated.

All the patients followed a computerized tomography (CT) protocol for the skull in the first postoperative week in order to investigate hemorrhagic complications associated with the graft. The choice for a CT scan in such an early postoperative period was due to better accuracy in diagnosing acute hemorrhages. A new CT scan was performed 30 and 90 days after the surgery so as to make sure there were no possible inflammatory reactions to the graft.

Magnetic resonance (MRI) can be useful in order to detect delayed inflammatory reaction and was performed in most of the patients. However, as it was not available for all the patients, the second CT was used as part of the protocol so as to standardize the results.

\section{RESULTS}

Only one patient, operated on a Chiari malformation type I, presented postoperative CSF fistula. None

Table 1. Type of graft and surgical technique applied.

\begin{tabular}{llcc}
\hline Type of graft & Technique & $\mathbf{n}$ & $\%$ \\
\hline Film & Suture & 4 & 13.3 \\
& Suture + glue & 1 & 3.3 \\
Sponge & Simple placement & 22 & 73.3 \\
& Placing + glue & 3 & 10.0 \\
\hline
\end{tabular}

Table 2. Location of the lesion treated with the dural graft.

\begin{tabular}{llcc}
\hline Location of graft & n & $\%$ \\
\hline Posterior fossa & $\begin{array}{l}\text { Cranial cervical junction } \\
\text { Posterior fossa }\end{array}$ & 6 & 36.6 \\
Supra tentorial & 5 & \\
& $\begin{array}{l}\text { Dural injury } \\
\text { Tumor infiltration }\end{array}$ & 9 & 36.6 \\
Spine & 2 & \\
Floor of the sella turcica & 6 & 20.0 \\
\hline
\end{tabular}


of the patients presented wound infections, hydrocephalus, pseudomenigocele, meningites or brain abscesses. No alterations were found in the postoperative CT scans, such as pneumocephalus, dural thickening, or graft-related problems. Two patients died during the study. One of them developed a severe brain edema secondary to venous injury at surgery on a giant olfactory groove meningioma. The other, operated on an intraventricular tumor, died after a bleeding in the posterior fossa right after surgery. It is clear that neither of the deaths were related to the dural graft.

Table 2 shows the topographic distribution of the treated lesions. The age average of patients with supratentorial dural lesions was 57 years, different from the overall mean age of 48.4 years, pointing to age as a relevant factor when considering the need for duroplasty in the supratentorial location. It is also possible to notice that the need for duroplasty is considerably higher in the posterior fossa, as the dura tends to retract and, therefore, makes it more difficult to obtain a watertight closure.

The indication for duroplasty was decided by the neurosurgical team during surgery. All patients participating in the study signed an informed consent term prior to surgery. Table 2 shows the indications for the use of the implant (Duradry) in this series. The use of the heterologous graft facilitated the operation considerably, reducing surgical time and the need for a new surgical incision in order to later remove other possible grafts, such as fascia lata ${ }^{4,5}$. In spinal surgeries, where it is usually difficult to suture a graft, the use of Duradry was also useful so as to reduce surgical time. Moreover, no fistula was observed in such cases ${ }^{6}$.

There was only one case of CSF fistula in this series. It was the surgical treatment of a Chiari malformation in which the matrix collagen graft was used. The patient developed a fistula and also meningitis, being treated with external lumbar drainage for 7 days and antibiotics. As the fistula remained, he was re-operated and a hole in the dura was found. A new film graft was used so as to close the fistula and the patient recovered well.

\section{DISCUSSION}

Galea aponeurotica or fascia lata are the most usual autologous grafts used in duroplasty. In cases it is not possible to use them, 6 heterologous dural substitutes are needed. All dural substitutes, particularly the heterologous ones, may be the cause of potentially serious complications, such as infections and inflammatory reaction to a foreign body. In the 1950's, lyophilized dura mater of cadavers was used, as it was easy to obtain and to handle. However, complications like prion infection made it impossible to keep its use $\mathrm{e}^{7-16}$.

Dural grafts obtained from various animal tissues, such as pericardium, intestinal mucosa and peritoneum, were progressively tested, used and, later, abandoned, due to the risk of zoonoses transmission, particularly bovine spongiform encephalopathy ${ }^{4,7}$. Various synthetic materials have been developed for dural grafting ${ }^{18-21}$. In theory, those would be the ideal grafts because of the availability and standardization in production. However, several reports on the use of such grafts showed severe complications related to their non-incorporation and development of chronic inflammatory reactions, even though several synthetic dural grafts are still in use with good results ${ }^{17,22,23}$.

More recently, dural substitutes made from animal purified collagen have been increasingly used with good outcomes. These grafts are prepared in such a manner that they contain only chemically acellular collagen with no other animal protein. This reduces the potential antigenic and infectious risk ${ }^{2,6,24,25}$. The grafts based on animal collagen naturally have a network of fibrils that promotes adherence, growth and proliferation of fibroblasts which will incorporate the graft and produce a new dural coverage. The low antigenic potential tends to prevent from adherence to the brain.

The material used in this study is similar to some dural grafts already available in the market (Tissudura Baxter, Duragen - Integra ${ }^{26-30}$. Our goal was to demonstrate the ease of use, the quality and the low incidence of reactions to this new dural substitute, derived from acellular bovine collagen.

In the present study, inflammatory reactions related to the use of the product were not observed, and no specific technical difficulty in its management was noticed. Regarding the prevention of CSF fistula, the result was also appropriate.

Our results show that the dural substitute used in this study is effective and safe. Longer term follow-up and a larger number of patients are necessary to confirm the absence of complications and adverse effects related to Duradry. However, we can conclude that the initial results of this new material are similar to those of other dural substitutes available in the market and reported in the literature.

\section{REFERENCES}

1. Esposito F, Cappabianca P, Fusco M, et al. Collagen-only biomatrix as a novel dural substitute examination of the efficacy, safety and outcome: clinical experience on a series of 208 patients. Clin Neurol Neurosurg 2008;110:343-351.

2. Knopp U, Christmann F, Reusche E, Sepehrnia A. A new collagen biomatrix of equine origin versus a cadaveric dura graft for the repair of dural defects: a comparative animal experimental study. Act Neurochir 2005; 147:877-887.

3. Danish SF, Samdani A, Hanna A, Storm P, Sutto L. Experience with acellular human dura and bovine collagen matrix for duraplasty after posterior fossa decompression for Chiari malformations. J Neurosurg Pediatr 2006;104:16-20. 
4. Fillipi R, Scwarz M, Voth D, Reisch R, Grunert P, Perneczky A. Bovine pericardium for duraplasty: clinical results in 32 patients. Neurosurg Rev 2001; 24:103-107.

5. Hida K, Yamaguchi S, Seki T, et al. Nonsuture dural repair using polyglycolic acid mesh and fibrin glue: clinical application to spinal surgery. Surg Neurol 2006;65:136-142

6. Narotam P, Reddy K, Fewer D, Qiao F, Nathoo N. Collagen matrix duraplasty for cranial and spinal surgery: a clinical and imaging study. J Neurosurg 2007;106:45-51.

7. Brooke FJ, Boyd A, KlugGM, Masters CL, Collins SJ. Lyodura use and the risk of iatrogenic Creutzfeldt-Jakob disease in Australia. Med J Aust 2004; 180:177-181.

8. Cantore G, Guidetti B, Delfini R. Neurosurgical use of human dura mater sterilized by gamma rays and stored in alcohol: long-term results. J Neurosurg 1987;66:93-95.

9. Esmonde T, Lueck CJ, Symon L, Duchen LW, Will RG. Creutzfeldt-Jakob disease and lyophilised dura mater grafts: report of two cases. J Neurol Neurosurg Psychiatry 1993;56:999-1000.

10. Fushimi M, Sato K, Shimizu T, Hadeishi H. PLEDs in Creutzfeldt-Jakob disease following a cadaveric dural graft. Clin Neurophysiol 2002;113: 1030-1035.

11. Heath CA, Barker RA, Esmonde TFG, et al. Dura mater-associated Creutzfeldt-Jakob disease: experience from surveillance in the UK. J Neurol Neurosurg Psychiatry 2006;77:880-882.

12. Hoshi K, Yoshino H, Urata J, Nakamura Y, Yanagawa H, Sato T. CreutzfeldtJakob disease associated with cadaveric dura mater grafts in Japan. Neurology 2000;55:718-721.

13. Lane K, Brown P, Howell D, et al. Creutzfeldt-Jakob disease in a pregnant woman with an implanted dura mater graft. Neurosurgery 1994;34: 737-740.

14. Martínez-Lage JF, Rábano A, Bermejo J, et al. Creutzfeldt-Jakob disease acquired via a dural graft: failure of therapy with quinacrine and chlorpromazine. Surg Neurol 2005;64:542-545.

15. Nishida Y, Yamada M, Hara K, et al. Creutzfeldt-Jakob disease after Jannetta's operation with cadaveric dura mater graft: initial manifestations related to the grafted site. J Neurol 2002;249:480-483.

16. Preusser M, Ströbel T, Gelpi E, et al. Alzheimer-type in a 28 year old patient with iatrogenic Creutzfeldt-Jakob disease after dural grafting. J Neurol Neurosurg Psychiatry 2006;77:413-416.

17. Parizek J, Mericka P, Husck Z, et al. Detailed evaluation of 2959 allogeneic and xenogeneic dense connective tissue grafts (fascia Lata, pericardium and dura mater) used in the course of 20 years for duroplasty in neurosurgery. Acta Neurochir 1997;139:827-838.

18. Vakis A, Koutentakis D, Karabetsos D, Kalostos G. Use of polytetrafluoroethylene dural substitute as adhesion preventive material during craniectomies. Clin Neurol Neurosurg 2006;108:198-802.

19. Sherman J, Pouratian N, Okonkwo D, Jane Jr J, Laws E. Reconstruction of the sellar dura in transsphenoidal surgery using an expanded polytetrafluoroethylene dural substitute. Surg Neurol 2008;69:73-76.

20. San Galli F, Vincent D, Rivel J, Baquey C, Ducassou D, Guérin J. Experimental evaluation of a collagen-coated vicryl mesh as a dural substitute. Neurosurgery 1992;30:396-401.

21. Mello LR, Feltrin LT, Fontes Neto PT, Ferraz FAP. Duraplasty with biosynthetic cellulose: an experimental study. J Neurosurg 1997;86:143-150.

22. Gudmundsson G, Søgaard I. Complications to the use of vicryl-collagen dural substitute. Act Neurochir 1995;132:145-147.

23. Cohen AR, Aleksic S, Ransohoff J. Inflammatory reaction to synthetic dura substitute. J Neurosurg 1989;70:633-635.

24. Narotam PK, Van Dellen JR. Bhoola KD. A clinicopathological study of collagen sponge as a dural graft in neurosurgery. J Neurosurg 1995;82:406-412.

25. Zahrai A, Shah J, Narotam P, Goytan M. A prospective clinical study of the use of collagen matrix as dura in spine surgery. J Bone Joint Surg 2005 87(Suppl 3):S295

26. Thadani V, Penar PL, Patington J, et al. Creutzfeldt-Jakob disease probably acquired from a cadaveric dura mater graft. J Neurosurg 1988;69:766-769.

27. Narotam P, Jose S, Nathoo N, Taylon C, Vora Y. P63. Collagen matrix (Duragen) in spinal durotomy: technique appraisal and clinical results. Spine J 2003;3:147-148.

28. Narotam P, Van Dellen J, Bhoola K. Experimental evaluation of collagen sponge as a dural graft. Br J Neurosurg 1993;7:635-641.

29. Narotam PK, José S, Nathoo N, et al. Collagen matrix (DuraGen) in dural repair: analysis of a new modified technique. Spine 2004;29:2868-2869.

30. Maurer PK, Mcdonald JV. Vicryl (polyglactin 910) mesh as a dural substitute. J Neurosurgery 1985;63:448-452. 